Review

\title{
Safety, Tolerability, and Immunogenicity of Interferons
}

\author{
Michael G. Tovey * and Christophe Lallemand \\ Laboratory of Viral Oncology, FRE2937 CNRS, Institut André Lwoff, 7 rue Guy-Moquet, 94801 \\ Villejuif, France \\ * Author to whom correspondence should be addressed; E-Mail: tovey@vjf.cnrs.fr; \\ Tel.: +331495834 23; Fax: +3314958 3444 .
}

Received: 9 March 2010; in revised form: 3 April 2010 / Accepted: 12 April 2010 /

Published: 20 April 2010

\begin{abstract}
Interferons (IFNs) are class II cytokines that are key components of the innate immune response to virus infection. Three IFN sub-families, type I, II, and III IFNs have been identified in man, Recombinant analogues of type I IFNs, in particular IFN 22 and IFN $\beta 1$, have found wide application for the treatment of chronic viral hepatitis and remitting relapsing multiple sclerosis respectively. Type II IFN, or IFN gamma, is used principally for the treatment of chronic granulomatous disease, while the recently discovered type III IFNs, also known as IFN lambda or IL-28/29, are currently being evaluated for the treatment of chronic viral hepatitis. IFNs are in general well tolerated and the most common adverse events observed with IFN $\alpha$ or IFN $\beta$ therapy are "flu-like" symptoms such as fever, headache, chills, and myalgia. Prolonged treatment is associated with more serious adverse events including leucopenia, thrombocytopenia, increased hepatic transaminases, and neuropsychiatric effects. Type I IFNs bind to high-affinity cell surface receptors, composed of two transmembrane polypeptides IFNAR1 and IFNAR2, resulting in activation of the Janus kinases Jak1 and Tyk2, phosphorylation and activation of the latent cytoplasmic signal transducers and activators of transcription (STAT1) and STAT2, formation of a transcription complex together with IRF9, and activation of a specific set of genes that encode the effector molecules responsible for mediating the biological activities of type I IFNs. Systemic administration of type I IFN results in activation of IFN receptors present on essentially all types of nucleated cells, including neurons and hematopoietic stem cells, in addition to target cells. This may well explain the wide spectrum of IFN associated toxicities. Recent reports suggest that certain polymorphisms in type I IFN signaling molecules are associated with IFN-induced neutropenia and thrombocytopenia in patients with chronic hepatitis $\mathrm{C}$. IFN $\gamma$ binds to a
\end{abstract}


cell-surface receptor composed of two transmembrane polypeptides IFGR1 and IFGR2 resulting in activation of the Janus kinases Jak1 and Jak2, phosphorylation of STAT1, formation of STAT1 homodimers, and activation of a specific set of genes that encode the effector molecules responsible for mediating its biological activity. In common with type I IFNs, IFN $\gamma$ receptors are ubiquitous and a number of the genes activated by IFN $\gamma$ are also activated by type I IFNs that may well account for a spectrum of toxicities similar to that associated with type I IFNs including "flu-like" symptoms, neutropenia, thrombocytopenia, and increased hepatic transaminases. Although type III IFNs share the major components of the signal transduction pathway and activate a similar set of IFN-stimulated genes (ISGs) as type I IFNs, distribution of the IFN $\lambda$ receptor is restricted to certain cell types suggesting that IFN $\lambda$ therapy may be associated with a reduced spectrum of toxicities relative to type I or type II IFNs. Repeated administration of recombinant IFNs can cause in a break in immune tolerance to self-antigens in some patients resulting in the production of neutralizing antibodies (NABs) to the recombinant protein homologue. Appearance of NABs is associated with reduced pharmacokinetics, pharmacodynamics, and a reduced clinical response. The lack of cross-neutralization of IFN $\beta$ by anti-IFN $\alpha$ NABs and vice versa, undoubtedly accounts for the apparent lack of toxicity associated with the presence of anti-IFN NABs with the exception of relatively mild infusion/injection reactions.

Keywords: cytokines; interferons; interleukins; innate immunity; Toll-like receptors

\section{Introduction}

Interferons (IFNs) are class II cytokines that play a determining role in the innate immune response to virus infection and in the establishment of the subsequent adaptive immune response leading to long-term antiviral immunity [1-3]. The human IFN super-family is comprised of three sub-families, type I, II, and III [3,4]. In man, the type I IFN family of intron-less genes is located on the short arm of chromosome 9 and encodes 12 functional IFN $\alpha$, and single IFN $\beta, \operatorname{IFN} \omega$, IFN $\varepsilon$, and IFNא subtypes. All type I IFNs bind to a common high-affinity hetrodimeric cell surface receptor composed of two transmembrane polypeptide chains, IFNAR1 and IFNAR2. IFN binding results in the phosphorylation and activation of two Janus kinases, Tyk2 and Jak1, associated with the cytoplasmic domains of IFNAR1 and IFNAR2 respectively, and the formation of docking sites for the latent cytoplasmic signal transducers and activators of transcription (STAT) 1 and 2. Tyk2 and Jak1, that in turn phosphorylate and activate STAT1 and STAT2, leading to the formation of a transcription complex in association with IFN regulatory factor 9 (IRF9). Translocation of this complex to the nucleus results in the transcriptional activation of a specific set of genes that encode the effector molecules responsible for mediating the biological activities of the type I IFNs including antiviral proteins such as MxA and 2',5' oliogadenylate synthetase, and immune modulatory proteins such as major histocompatibility antigens (MHC) [1-4]. Type I IFNs can, however, phosphorylate and activate other signaling molecules including STAT3, STAT4, Map kinases, and PI-3 kinase [5,6]. Although all the type I IFNs appear to induce comparable qualitative biological activities there are quantitative differences in the 
activity of different sub-types which is reflected in a different spectrum of clinical activity [3]. Several regulatory mechanisms exist for modulating the action of type I IFNs both at the level of receptor expression and at the level of subsequent down-stream signaling. Regulation of receptor expression is a common mechanism for modulating cytokine responsiveness and it has been shown that the type I IFN receptor is internalized and degraded after ligand binding [7-9], and that after prolonged IFN $\alpha$ therapy, patients displayed a state of decreased receptor expression, that correlated with a favorable response to IFN therapy [10,11]. In contrast, a negative correlation has been reported between expression of IFNAR2a, a soluble isoform of IFNAR2 produced by alternative splicing, and responsiveness to IFN $\beta$ treatment in patients with RRMS [11], suggesting that production of soluble IFNAR2a can sequester IFN $\beta$ thereby inhibiting IFN $\beta$ activity and constituting a negative feedback loop. A number of negative regulatory molecules have been described including SOCS-1, UBP43, PIAS, and SHP-2 that act to down-regulate IFN signaling in order to prevent over stimulation of the IFN signaling pathway that could lead to the development of autoimmunity. Thus, SOCS-1 binds to the C-terminal region of IFNAR1 preventing binding of Tyk2, while UBP43 blocks the interaction of Jak1 with IFNAR2. PIAS (protein inhibitor of activated STAT) promotes SUMOylation of STAT proteins including STAT3 in a manner that resembles the action of the RING-type ubiquitin E3 ligases. SHP-2 is involved in STAT dephosphorylation and regulation of nuclear export [12].

In man, a single type II IFN has been described commonly known as interferon gamma (IFN $\gamma$ ) which is encoded by a single copy intron-containing gene located on chromosome 12. IFN $\gamma$ binds to a specific cell surface receptor composed of two trans-membrane polypeptides, IFNGR1 and IFNGR2 and signals through a STAT1 homo-dimer resulting in the transcriptional activation of a specific set of genes, that encode the effector molecules responsible for mediating its biological activity. A number of the genes activated by IFN $\gamma$ are also induced by type I IFNs [3,4]. In contrast to the type I IFN that are produced by most cell types in response to virus infection, IFN $\gamma$ is produced primarily by T-cells and NK cells in response to specific antigen or mitogens and plays a key role in T-cell activation and the establishment of the adaptive immune response [13,14]. A third IFN sub-family, the type III IFNs, has also been described recently $[15,16]$. In man, three individual type III IFNs have been identified, IFN $\lambda 1$, IFN $\lambda 2$, and IFN $\lambda 3$, that are also known as IL-29, IL-28A, and IL-28B respectively. All three proteins are encoded by genes located on chromosome 19 [17] and bind to a specific cell-surface receptor comprising a unique IFN $\lambda$ R 1 chain and the IL-10R2 chain, which is also shared, by the IL-10, IL-22, and IL-26 receptors [17]. Type III IFNs share a common signaling pathway with the type I IFNs, and activate the transcription of effector protein encoding genes [15-17]. In marked contrast, however, to type I IFNs, the type III IFN receptor is expressed only on certain cell types [15-17].

\section{Type I Interferons}

Type I IFNs exhibit antiviral, antiproliferative, and immunomodulatory activities and play a key role in the innate immune response to virus infection. Type I IFNs also enhance the expression of a number of apoptotic or pro-apoptotic genes including FAS, FAS ligand, pro-caspase 2 and 8, TRAIL, Bak, Bax, and the transcription factors IRF1 and IRF3 [18] IRF1 and IRF3 play a central role in the regulation of the interferon system and are themselves in turn induced by type I IFNs constituting a positive feed-back loop. Furthermore, IRF1 and IRF3 are also involved in the pro-apoptotic activity of the type I IFNs. Thus, the presence of infectious virus, inactivated viral particles, or viral component 
such as dsRNA, induce post-translational modification of IRF1 and IRF3 resulting in marked transcriptional activation of the apoptotic gene NOXA resulting in apoptosis of virus-infected cells [19], increased numbers of apoptotic vesicles, and enhanced presentation of viral peptides by IFNactivated dendritic cells (DCs). Thus, type I IFNs produced principally by plasmacytoid dendritic cells (pDCs) also play an important role in the establishment of the adaptive immune response by stimulating dendritic cell maturation through increased expression of co-stimulatory molecules including CD40, CD80, and CD86, and major histocompatability complex (MHC) antigens [20], and presentation of pathogen-derived antigens to naïve T-cells. Thus, following activation, DCs present virus-derived peptides on MHC class I antigens to CD8+ T leading to CD8+ T-cell activation [21]. Type I IFNs play an important role in this process, known as cross priming, independent of the CD40 ligand-CD40 interaction between DCs and CD + T-cells [21-23]. IFN $\alpha$ can stimulate the priming and differentiation of naïve CD4+ lymphocytes potentiating a Th1 type response characterized by the production of IFN $\gamma$ [24]. IFN $\alpha$ can also activate memory CD4+ T-cells when exposed to cognate antigen [25]. IFN can act directly on memory T-cells to increase their survival and indirectly through stimulation of IL-15 production by antigen presenting cells (APCs) that contributes to the survival of memory T cells [26,27]. Type I IFNs have been shown to induce B-lymphocytes to differentiate into antibody producing plasma cells [28] and to be necessary for the production of both specific and polyclonal IgG in response to virus infection and to stimulate isotype switching [29].

Recombinant analogues of IFN $\alpha 2$ and IFN $\beta 1$, and more recently pegylated forms of IFN 2 , have found wide application for the treatment of chronic viral hepatitis and remitting relapsing multiple sclerosis (RRMS) respectively. Pegylated IFNs exhibit improved pharmacokinetics allowing less frequent injections without a loss of therapeutic activity [30]. Pegylated IFNs exhibit similar adverse events to those observed with the native molecule, however, even though plasma levels are more constant and peak-to-trough levels associated with frequent administration are reduced [31]. Pegylated IFN $\alpha 2 a$ (PEG-IFN $\alpha 2 a)$ or PEG-IFN $\alpha 2 b$ in combination with ribavirin is currently standard treatment for patients with chronic hepatitis $\mathrm{C}(\mathrm{HCV})$ and compensated liver disease [32]. IFN $\beta 1 \mathrm{a}$, and IFN $\beta 1 \mathrm{~b}$ are also widely used as first-line therapy for RRMS an autoimmune disease characterized by the presence of auto reactive T-cells in the central nervous system (CNS), demyelination, and axonal damage [33]. Type I IFNs are also used to treat neoplastic disease including hematological malignancies and solid tumors [34]. Thus, IFN 22 has been used to treat chronic hairy cell leukemia [34] chronic myelogenous leukemia [34], non-Hodgkin's lymphoma in combination with chemotherapy [34], and is used as an adjuvant to surgical restriction for the treatment of malignant melanoma [34,35].

Interferon induced adverse events are usually dose-dependant and to some extent a function of the IFN sub-species employed, the disease state, and the genetic makeup of the individual being treated. Adverse events include acute flu-like symptoms and sub-acute and chronic side effects such as myelosuppression, neuropsychiatric effects, and induction or exacerbation of underlying autoimmune disease.

\subsection{Acute Adverse Events}

Most patients treated with standard therapeutic doses of native or pegylated IFN $\alpha 2$ or IFN $\beta 1$ exhibit flu-like symptoms including fever, headache, chills, and myalgia within 1 to 3 hours of the 
initiation of IFN treatment. These symptoms decrease in intensity over time [36], and are believed to be due to both the release of the inflammatory cytokines IL-1, IL-6, and TNF $\alpha$ and induction of prostaglandin-E2 in the hypothalamus [37].

\subsection{Sub-Acute and Chronic Side-Effects}

\subsubsection{Myelosuppression}

Neutropenia is one of the most common adverse events observed in patients with chronic hepatitis $\mathrm{C}$ treated with native or pegylated IFNa2a or IFN $\alpha 2 b[31,36]$. Neutropenia can be sufficiently severe to necessitate dose-reduction in some $20 \%$ of patients and discontinuation of treatment in 2 to $6 \%$ of patients [31,36]. Anemia is also responsible for dose reduction in 25 to $28 \%$ of patients with chronic $\mathrm{HCV}$ infection treated with IFN $\alpha 2$ in combination with ribavirin $[31,36]$. Thrombocytopenia is also observed in approximately $6 \%$ of patients with chronic hepatitis $C$ treated with PEG-IFN $\alpha 2 a$ or PEGIFN $2 \mathrm{~b}$ and often leads to dose reduction or discontinuation of treatment [38]. Hematological adverse events can be particularly severe in patients co-infected with HCV and HIV and treated with pegylated IFNa2 and ribavirin [39]. Sever hematological toxicity following IFN treatment is associated with cirrhosis, and low base-line body weight and hemoglobin levels [39]. The anti-proliferative effects of type I IFNs are thought to be responsible at least in part for the myleosuppression observed during IFN treatment. Thus, we have shown that human hematopoietic progenitor cells express functional type I IFN receptors [40] and IFN $\alpha$ has been shown to inhibit colony formation by human erythroid, myeloid, and megakaryocyte progenitor cells [41]. IFN $\alpha$-induced leucopenia is also thought to result from an effect of IFN $\alpha$ on leukocyte trafficking between the peripheral circulation and lymphoid organs [36]. IFN-induced thrombocytopenia is thought to be due to an inhibition of megakaryocyte maturation and platelet production rather than an effect on megakaryocyte proliferation or endomitosis [42]. Thus, IFN $\alpha$ has been shown to inhibit the expression of GATA-1, p45 ${ }^{\mathrm{NF}-\mathrm{E} 2}$, and Mafg, transcription factors involved in late-stage megakaryopoiesis [42]. An association between polymorphisms in the genes encoding IFNAR1 and STAT2, and IFN-induced neutropenia has recently been reported in a Japanese population with chronic hepatitis C treated with type I IFN [43]. Similarly, IFN-induced thrombocytopenia was found to be associated with a polymorphism in the gene encoding IRF7 [43]. In contrast, these polymorphisms were not associated with a sustained virologic response to IFN therapy that was dependent upon independent factors including viral load, viral genotype and the degree of liver fibrosis on initiation of IFN treatment [43]. It will be of considerable interest to determine whether the same polymorphisms are also associated with IFN-induced hematological adverse events in populations of different ethnic origins.

\subsubsection{Hepatic toxicity}

Elevated levels of liver transaminases are a common side effect observed during the first weeks of treatment of patients with IFN $\alpha$. The effects are dose-dependant and resolve rapidly on cessation of IFN therapy. The mechanisms underlying these effects remain unclear [36]. 


\subsubsection{Autoimmune Disease Associated With Interferon Therapy}

Apparent induction or exacerbation of preexisting autoimmune disease is a relatively frequent occurrence in patients treated with type I IFNs; cytokines that can affect both innate and adaptive immunity $[44,45]$. The genetic background of the individual as well as the characteristics of the disease treated will determine to a large extent the manifestations of autoimmune disease observed. Recent genome-wide association studies have identified alleles associated with susceptibility to a number of autoimmune diseases such as systemic lupus erythematosus (SLE) or Sjogren's Syndrome (SS), some of which encode proteins involved in IFN induction or signaling pathways [46-55].

\subsubsection{Systemic lupus erythematosus (SLE), Cutaneous lupus erythematosus (CLE)}

There are a number of reports of the induction or exacerbation of SLE, a disease that involves multiple internal organs, and CLE, which is limited to the skin, in patients treated with recombinant IFN $[45,56,57]$. Patients with particular MHC class I and Class II haplotypes, female gender, and other risk factors, that predispose an individual to the development of autoimmune disease, are particularly susceptible to the development of IFN-induced SLE or CLE. The symptoms of IFNinduced SLE or CLE usually resolve after discontinuation of IFN treatment [45,56,57]. Although the mechanism(s) of IFN-induced SLE and CLE remain unclear, IFN $\alpha$ has been detected in the peripheral circulation of untreated SLE patients and a number of studies have shown an association between activation of the type I IFN pathway and disease activity [58,59]. Thus, the expression of a number of ISGs, often referred to as an "IFN signature", is up regulated in peripheral blood mononuclear cells (PBMC) from SLE patients with active disease [58,60]. Furthermore, polymorphisms in the genes encoding IRF-5 and Tyk2, that play key roles in induction and the activity of IFN $\alpha$ respectively, have been identified as risk factors for the development of SLE [50,51]. A single nucleotide polymorphism (rs7574865) in the gene encoding the STAT4 protein, a transcription factor that is phosphorylated and activated following binding of IFN $\alpha$ to its receptor, has also been shown to be associated with risk of SLE in a population of European ancestry [61]. It has been suggested that auto-antibodies present in patients with SLE can form soluble immune complexes with RNA or DNA released by apoptotic or necrotic cells, and that these immune complexes are taken up by pDC leading to production of type I IFNs in a TLR-dependant [59]. It has also been reported that IRF-5, which is involved in induction of IFN 22 in the TLR 7/8 pathway, is expressed constitutively in pDCs [59]. Up-regulation of the IFN $\alpha$ inducible gene MxA is also observed in skin lesions of patients with CLE [56] that also contain large numbers of IFN-producing pDCs [62,63]. There is also evidence to suggest that IFN $\alpha$ is involved in the pathogenesis of the neuropsychiatric manifestations observed in some patients with SLE [64].

\subsubsection{Sjogren's syndrome}

Treatment of patients with standard therapeutic doses of type I IFNs has been reported to induce the symptoms of Sjogren's syndrome $[65,66]$. Sjogren's Syndrome is a relatively common systemic inflammatory disease characterized by production of antinuclear antibodies and a chronic cellular infiltration of the exocrine glands, in particular salivary and lachrymal glands leading to dry mouth (xerostomia) and dry eyes (keratoconjunctivitis sicca) respectively [67,68]. The cellular infiltrate consists principally of CD4+ T-cells, B-cells, and dendritic cells, including IFN $\alpha$ secreting pDCs [69]. 
It has been suggested that auto-antibodies present in patients with SS may form soluble immune complexes with U1 snRNA released by apoptotic or necrotic cells, and that these immune complexes are taken up by pDCs leading to production of IFN $\alpha$ via a mechanism involving TLR-7/8 [70]. In common with SLE, SS is characterized by enhanced expression of a number of ISGs and a type I IFN signature of gene expression is observed in both PBMCs and salivary glands [54,69-71]. Again in common with SLE, polymorphisms in the genes encoding IRF5 and STAT4, key transcription factors involved in IFN induction and action respectively, have been reported to be associated with SS in a number of different populations [52-54,72]. In contrast to these observations, both parenteral administration of moderate doses of IFN $\alpha$, that is 1 to $2.3 \times 10^{6}$ IU once to three times weekly respectively, or oral administration of low levels of IFNa (150 IU three times a day), have been reported to relieve the symptoms of xerostomia and xerophthalmia in patients with primary Sjogren's Syndrome [73-79]. The mechanisms underlying these seemingly paradoxical effects remain to be elucidated.

\subsubsection{Dermatomyositis and polymyositis}

The connective tissue diseases dermatomyositis and polymyositis, are characterized by underlying autoimmune abnormalities and up-regulation of numerous ISGs in various tissue of patients with active disease [80-82]. Both IFN $\alpha 2$ and IFN $\beta 1$ have been reported to induce or exacerbate dermatomyositis and polymyositis in some patients [82,83], and it have been suggested that as in the case of SLE and SS, RNA or DNA contained in soluble immune complexes taken up by pDCs interacts with TLRs in endosomal vesicles leading to local over-production of type I IFNs in skin and muscle [80-82].

\subsubsection{Systemic sclerosis}

The rs7574865 polymorphism in the STAT4 gene and the rs2004640 polymorphism in the IRF5 gene are also associated with a predisposition to systemic sclerosis, an autoimmune connective tissue disorder characterized by fibrosis of multiple organs and a type I IFN signature [72,84,85]. Systemic sclerosis has been reported to occur following treatment with IFN $\beta 1$ [86]. IFN $\alpha 2$ has been reported to induce or exacerbate peripheral neuropathy in patients with $\mathrm{HCV}$-associated mixed cryoglo-bulinemia [87]. There are also case reports of demyelinating neuropathies developing during IFN $\alpha 2$ treatment of patients with chronic hepatitis $\mathrm{C}$ without cryoglobulinemia [87]. Although it is well established that type I IFNs can enhance antibody production, up-regulate MHC class I antigen expression, and stimulate Th1 type immunity all of which may contribute to autoimmunity, the mechanism(s) by which IFN $\alpha$ exacerbates the autoimmune mechanisms underlying these diseases remains unclear [87].

\subsubsection{Rheumatoid arthritis (RA) and psoriatic arthritis}

Exacerbation of the symptoms of RA or psoriatic arthritis has been reported in patients with chronic $\mathrm{HCV}$ infection or various malignancies treated with IFN 2 2, and in patients with RRMS treated with IFN $\beta 1[88,89]$. Induction of new-onset RA is a relatively infrequent event in IFN-treated patients, and symptoms often resolve after cessation of treatment $[88,90]$. Symptoms may persist, however, in patients with a genetic predisposition $[45,88]$. In common with other autoimmune diseases such as 
SLE, single nucleotide polymorphisms in the gene encoding IRF5 have been shown to be associated with susceptibility to RA [91].

\subsubsection{Type I diabetes}

IFN $\alpha$ has been reported to induce symptoms of insulin-dependent type I diabetes in patients with chronic hepatitis $\mathrm{C}$ infection; for the most part in individuals with pre-existing autoimmunity and/or with a genetic predisposition [45,92]. As in the case of other autoimmune diseases the action of IFN $\alpha$ may be related to increased expression of MHC class I antigens, enhanced expression of costimulatory molecules, and activation of DCs as well as stimulation of immunoglobulin synthesis and increased autoantibody production, and an enhanced T-cell response leading to the destruction of pancreatic $\beta$-cells. There is also convincing evidence from both clinical studies and animal models to suggest that IFN $\alpha$ is indeed involved in the pathogenesis of type I diabetes [92-95].

\subsubsection{Autoimmune hepatitis}

Some cases of autoimmune hepatitis have been reported in patients with chronic HCV infection, or malignancies treated with IFN $\alpha$ and in patients with RRMS treated with IFN $\beta 1$ [96-102]. Autoimmune hepatitis is a rare but sever adverse event in IFN-treated patients that is often life threatening and is associated with certain HLA haplotypes [96-102].

\subsubsection{Neuropsychiatric effects associated with Interferon therapy}

Treatment of patients with chronic HCV infection with native or pegylated IFN $\alpha$ is associated with a number of neuropsychiatric side-effects including fatigue, depression, cognitive disturbances and in some cases suicidal tendencies [103]. IFN $\alpha$ can also cause cognitive dysfunction that dissipates on cessation of IFN treatment [103,104]. Although some of these effects may be due in part to the consequences of somatic toxicity they may also be due to effects of IFNs on neurons, serotonergic activity, neuroendocrine cytokine secretion, tryptophan metabolism and neurotransmitters. IFN $\alpha$ has to affect the hypothalamic-pituitary-adrenal system by activating corticotrophin-releasing factor [64,102,103-108]. Several studies have also shown that IFNa can cause changes in the electrophysiological activity of the brain [64,102-108]. Increased circulating levels of IL6 observed during IFN $\alpha$ therapy are associated with symptoms of depression and high levels of IL6 prior to treatment are predictive of depression during IFN treatment [109,110]. Functional polymorphisms in the promoter of the IL6 gene and in the promoter region of the serotonin transporter (5-HTT) gene [111] have been shown to be associated with a lower risk of symptoms of depression during IFN $\alpha$ treatment. Neither polymorphism, however, affects the development of fatigue that occurs during IFN $\alpha$ therapy [111].

Systemic administration of type I IFNs can result in activation of IFN receptors present on essentially all types of nucleated cells, including neurons [104,112]. Although type I IFNs do not cross the blood-brain barrier under physiological conditions, permeability may be altered during virus infection, or during various inflammatory disease. IFNs can also active a number of cell types present in the central nervous system (CNS) such as neurons, astrocytes, microglia, as well as cells such as macrophages or T-lymphocytes that may enter the CNS in patients with chronic viral hepatitis, or 
inflammatory demyelinating disease [104,113]. Production of IFN $\alpha$ has also been implicated in the development of the neuropsychiatric effects, including psychosis, observed in some patients with SLE.

\subsubsection{Neuromuscular disorders associated with Interferon therapy}

Peripheral neuropathy is a rare adverse event observed in some patients with chronic hepatitis $\mathrm{C}$ treated with native or pegylated IFN $\alpha$ [87,113]. In patients with chronic myeloid leukemia or in HCVinfected patients with mixed cryoglobulinemia and neuropathy, IFN $\alpha$ has also been reported to either exacerbate pre-existing disease or induce new onset neuropathy [87,113]. Some cases of the development or exacerbation of pre-existing autoimmune demyelinating neuropathies have also been reported in patients with chronic hepatitis $\mathrm{C}$ treated with IFN $\alpha$ [87]. There are isolated case reports of axonal neuropathies associated with IFN $\alpha$ therapy although the pathogenesis of axonal injury by IFN $\alpha$ remains unknown [87]. IFN $\alpha$ treatment has also been reported to exacerbate myasthenia gravis in some HCV-infected patients, or in patients with various malignancies treated with IFN $[87,114,115]$. There are also isolated reports of the appearance of neuromotor abnormalities such as dystonia, chorea, myorhythmia, and Parkinson's disease in patients treated with native or pegylated IFN $\alpha[116,117]$. There is evidence from animal models to suggest that IFN $\alpha$ can exert an inhibitory effect on nigrostriatal dopaminergic transmission which may account at least in part for some of the Parkinson disease like symptoms observed in some patients [116-118].

\subsubsection{Thyroid dysfunction associated with Interferon Therapy}

Thyroid dysfunction including hypothyroidism and less frequently hyperthyroidism, is a relatively common side-effect of IFN treatment that occurs in approximately $6 \%$ of IFN treated patients, although the incidence varies considerably from one study to another [119]. IFN-induced thyroid dysfunction is often sub-clinical and resolves spontaneously in a majority of patients [119]. Both IFN $\alpha$ and IFN $\beta$ therapy are associated with the development of thyroid dysfunction and although differences in the dose and frequency of IFN treatment may well account in part for this variability, the incidence of thyroid dysfunction is higher in IFN-treated patients with pre-existing thyroid autoimmunity irrespective of the disease being treated [119]. Although the mechanisms leading to IFN-induced thyroid dysfunction remain unclear, immune modulation by type I IFNs may well exacerbate underlying immune dysfunction in patients with pre-existing thyroid autoimmunity. Direct effects of type I IFNs on thyroid cells resulting in an inhibition of iodine uptake and thyroxin secretion may also contribute to the thyroid dysfunction observed in IFN treated patients $[119,120]$.

\subsubsection{Sarcoidosis associated with Interferon Therapy}

Sarcoidosis is a chronic granulomatous disorder of unknown etiology that can affect numerous organs including the lungs, skin, eyes, and liver. Sarcoidosis involving most frequently the lungs and skin has been reported in a number of patients with chronic hepatitis $\mathrm{C}$ or various malignancies treated with native or pegylated IFN $\alpha[121,122]$ and less frequently in patients treated with IFN $\beta 1$. Symptoms tend to regress spontaneously either during treatment or after cession of IFN treatment [121-127]. It has been suggested that the induction or exacerbation of Sarcoidosis during IFN $\alpha$ therapy may be to IFN $\alpha$ stimulation of IFN $\gamma$ secreting activated T-lymphocytes [45]. 


\section{Interferon Lambda}

Recent independent genome-wide association studies have identified single nucleotide polymorphisms in the region of the IFN 33 (IL28B) gene that are associated with the response of patients with chronic HCV infection to treatment with PEG-IFNa2/ribavirin [128-130]. In common with type I IFNs, IFN $\lambda 3$ exhibits antiviral activity against $\mathrm{HCV}$ and small quantities of IFN $\lambda 3$ can potentiate the antiviral activity of IFN 2 and vice versa [131]. Although type III IFNs share a common signaling pathway with the type I IFNs, and activate the transcription of a similar set of interferon sensitive genes (ISGs) encoding IFN effector proteins [131], difference in the kinetics of ISG activation by IFN $\lambda 1$ and IFN $\alpha 2$ have been reported [131]. Furthermore, initial clinical studies with pegylated IFN $\lambda 1$ suggest that IFN $\lambda 1$ exhibited anti-HCV activity in the absence of the flu-like symptoms or hematological side effects associated with treatment with type I IFNs [132]. The most common side effects observed in patients with chronic HCV infection treated with PEG-IFN 1 were myalgia and fatigue [132]. These results may well be related to the more restricted distribution of the IFN $\lambda$ receptor expression. Thus, the IFN $\lambda$ receptor does not appear to be expressed on monocytes or lymphocytes [133] and the IL-10R2 chain of the IFN lambda receptor is expressed in very low levels in certain compartments of the brain [134]. Recent results have shown that IFN $\lambda$ has a relatively modest activity in the brain suggesting that the therapeutic use of IFN $\lambda$ may be associated with less neurological side effects [132]. IFN lambda in association with ribavirin and/or IFN 2 holds considerable promise for the treatment of chronic viral hepatitis with the prospect of less side effects than current treatment options.

\section{Interferon $\gamma$}

IFN $\gamma$ production is critical for the establishment of the adaptive immune response, T-helper Th1 cell response, and protective immunity against viruses and intracellular bacteria [14]. IFN $\gamma$ is produced principally by NK cells and activated T-cells in response to specific antigen, mitogens, IL-2, IL-12, and IL-18 upon subsequent stimulation with IL-12 [135]. IFN $\gamma$ plays an important role in the activation and differentiation of NK cells, B-cell, T-cells, and macrophages [14]. IFN $\gamma$ also enhances expression of MHC class II antigens on antigen presenting cells (APCs), increases antigen presentation to helper T-cells [135], and plays a key role in CD8+ T-cell activation [14].

Despite its key role in the establishment of the adaptive immune response, IFN $\gamma$ has not found wide application in the clinic $[135,136]$. IFN $\gamma$, is used principally for the treatment of chronic granulomatous disease (CDG), a rare congenital disorder characterized by a lack of superoxide and hydrogen peroxide production by macrophages and susceptibility to bacterial and fungal infections [136]. IFN $\gamma$ is also used for the treatment of congenital osteopetrosis a rare pediatric disorder characterized by a defect in osteoclast function [137]. IFN $\gamma$ alone has been shown to be without benefit in the treatment of chronic hepatitis B or chronic hepatitis $\mathrm{C}$ and to be poorly tolerated when combined with IFN $\alpha$ treatment [136]. Similarly, IFN $\gamma$ is not used for the treatment of multiple sclerosis and although IFN $\gamma$ has shown some benefit in the treatment of ovarian cancer it is has had not been widely used to treat neoplastic disease [14,136].

In common with type I IFNs, treatment with IFN $\gamma$ is generally well tolerated and the most common adverse events observed are "flu-like" symptoms including fever, chills, fatigue, headache, and 
myalgia similar to those observed in patients treated with type I IFNs [136,138]. IFN $\gamma$ treatment is also associated with reversible neutropenia and thrombocytopenia that may be severe in some patients, and marked increases in hepatic transaminases $[14,136,138]$. IFN $\gamma$ receptors are ubiquitous and a number of the genes activated by IFN $\gamma$ are also activated by type I IFNs. This may well account for a spectrum of toxicities similar to that associated with type I IFNs including "flu-like" symptoms, neutropenia, thrombocytopenia, and increased levels of hepatic transaminases. It is difficult to determine, however, whether other adverse effects observed in patients treated with type I IFNs, such as neuropsychiatric effects or induction or exacerbation of preexisting autoimmune disease would also be observed in patients treated with IFN $\gamma$ due to the relatively limited clinical application of IFN $\gamma$ therapy. Development of symptoms of SLE has been reported, however, in patients with RA treated with recombinant IFN $\gamma[139,140]$. IFN $\gamma$ has also been implicated in the pathogenesis of sarcoidosis, an autoimmune disease characterized by a Th1 dominant cytokine profile, with high levels of IL-12, IL18 , IFN $\gamma$, and IP-10, in the bronchoaleveolar lavage [141-145], it remains to be established whether treatment with recombinant IFN $\gamma$ would induce or exacerbate underlying sarcoidosis as has been reported in patients treated with IFN $\alpha$ [121-127] and in patients treated with IFN $\alpha$ combined with IFN $\gamma[146]$.

\section{Immunogenicity}

Repeated administration of recombinant IFN $\alpha 2$ or IFN $\beta 1$, can result in a break in immune tolerance to self-antigens in some patients resulting in the production of anti-IFN antibodies. These antibodies may bind to the IFN molecule in such a manner that they are largely without effect, or they may alter IFN pharmacokinetics, or in certain cases neutralize the activity of the IFN by binding to an epitope that prevents IFN from binding to its cell-surface receptor on target cells [147,148]. The results of a number of clinical studies have shown that the development of anti-IFN $\alpha$ antibodies occurs frequently in patients with chronic hepatitis $\mathrm{C}$ or neoplastic disease, treated with either IFN $22 \mathrm{a}$ or IFN $\alpha 2 b$ [149]. The incidence of anti-IFN antibody production is highly variable, however, and has been reported to vary from 7 to $60 \%$ [149]. A lack of assay standardization and differences in treatment regiments undoubtedly accounts in part for the apparent variation in the incidence of anti-IFN antibodies in patients treated with recombinant IFNa. In most of these studies, however, the incidence of neutralizing antibodies was low [149]. Pegylation increases the plasma half-life of IFN $\alpha$ permitting once-weekly dosing with improved efficacy compared with the native molecule. Pegylation is often considered to reduce the immunogenicity of recombinant proteins by PEG-induced steric hindrance and reduced immune recognition $[31,150,151]$. It has been reported, however, that some $8 \%$ of patients with chronic hepatitis $\mathrm{C}$ infection who failed to respond to therapy with pegylated IFN $\alpha 2$ and ribavirin, had circulating neutralizing anti-IFN $\alpha$ antibodies while none of the patients who cleared HCV following IFN therapy had detectable levels of anti-IFN $\alpha$ NAbs [152].

The incidence of anti-IFN antibodies appears to be higher in patients with RRMS treated with recombinant IFN $\beta 1$ than in patients with chronic hepatitis $C$ treated with either native or pegylated IFNa2 [149,153,154]. Direct comparisons are difficult however, due to different dosing regimens, differences in the duration of treatment, and differences in the genetic background of the individuals treated. In addition, differences in formulation can influence protein aggregation that can in turn affect immunogenicity [155]. The use of different assays and reference preparations can also influence the 
results obtained. It remains to be determined whether the apparent differences in the immunogenicity of IFN $\alpha$ or IFN $\beta$ subspecies are due to intrinsic differences in the primary structure or glycosylation of the molecules. Similarly, although differences in the immunogenicity of IFN $\beta 1$ a and IFN $\beta 1 b$ have been reported [156]. Thus, analysis of 846 patients with RRMS treated with IFN $\beta$ showed that $88 \%$ of patients receiving IFN $\beta 1$ b, $45 \%$ of patients treated with IFN $\beta 1$ a IM, and $56 \%$ treated with IFN $\beta 1$ a SC developed antibodies against IFN $\beta$ at some point during 1 to 4 years of treatment, and that neutralizing antibodies were detected in $37 \%, 12 \%$, and $51 \%$ of these patients, respectively [156]. It remains to be determined whether the apparent differences in the immunogenicity are due differences in primary structure or to the use of different expression systems and manufacturing procedures [155]. The results of a number of studies have shown that polyclonal antibodies produced in patients treated with IFN $2 \mathrm{a}$ or IFN $\alpha 2 b$ cross-neutralize both proteins as well as pegylated derivatives of either protein or native IFN $\alpha 1$ [152,157]. Similarly, sera from patients with RRMS treated with IFN $\beta 1$ a (Avonex or Rebif) have been shown to cross-neutralize IFN $\beta 1$ b (Betaferon). The lack of cross-neutralization of IFN $\beta$ by anti IFN $\alpha$ NABs and vice versa, undoubtedly accounts for the apparent lack of untoward effects associated with the presence of anti-IFN NABs with the exception of relatively mild infusion/injection reactions. This is in marked contrast to the sever autoimmune reactions associated with the presence of auto-antibodies to non-redundant essential proteins such as erythropoietin (EPO) or megakaryocyte growth and development factor (MGDF) that can result in pure red cell aplasia and sever thrombocytopenia respectively [158,159]. The results of a number of clinical studies have shown, however, that the development of anti-IFN NABs is associated with both reduced bioavailability and a reduced clinical response in patients treated with either IFN $\alpha 2$ or IFN $\beta 1$ [149,152-154]. Thus, in RRMS patients treated with IFN $\beta$ the development of anti-IFN NABs is associated with both reduced pharmacodynamics and reduced induction of IFN $\beta$ responsive gene products [147], and a reduced clinical response, determined by either magnetic resonance imaging (MRI) or disease progression [154, $160,161]$.

There is limited data available on the immunogenicity of IFN $\gamma$. It has been suggested that recombinant IFN $\gamma$ is not immunogenic, based on a study 334 patients most of whom were treated for short periods with IFN $\gamma$ in a series of Phase I and II clinical trials [162]. One patient, however, did develop transient non-neutralizing anti-IFN $\gamma$ antibodies after cessation of a three months intravenous treatment regimen [162]. Furthermore, there are several reports of the presence of IFN $\gamma$ autoantibodies in patients presenting with recurrent Mycobacterium infections [163-168].

\section{Conclusions}

Since their introduction in the early eighties recombinant interferons have found wide application for the treatment of chronic viral hepatitis, neoplastic disease, and remitting relapsing multiple sclerosis. A large body of information is now available on their efficacy, safety, tolerability, and immunogenicity. For the most part interferons are well tolerated, with the most common adverse events observed being "flu-like" symptoms that resolve rapidly after initial treatment. Prolonged treatment is associated, however, with more serious adverse events including leucopenia, thrombocytopenia, and neuropsychiatric effects that may necessitate dose reduction or even cessation of IFN treatment in some patients. Polymorphisms in type I IFN signaling molecules are associated with IFN-induced neutropenia, thrombocytopenia, and neuropsychiatric effects, raising the possibility 
that patients most likely to well tolerate IFN therapy can be identified. Similarly, polymorphisms in IFN signaling molecules are associated with IFN-induced autoimmune disease again suggesting that individuals may be stratified according to the risk of developing symptoms of autoimmune disease during IFN therapy. Repeated administration of recombinant IFNs can cause in a break in immune tolerance in some patients resulting in the production of a polyclonal antibody response that can adversely affect pharmacokinetics, and clinical response. Recent studies have shown that the immunogenicity of IFN $\beta 1$ can be reduced by changes in formulation [169] opening the way for less immunogenic and better-tolerated IFNs. The recently discovered type III IFNs that are currently in clinical development, bind to a receptor restricted to certain cell types suggesting that IFN $\lambda$ therapy may be associated with a reduced spectrum of toxicities relative to type I or type II IFNs, that bind to receptors present on essentially all nucleated cells. The results of initial clinical trails with PEG-IFN $\lambda 1$ suggest that the apparent absence of flu-like symptoms or hematological side effects may indeed be related to the relatively restricted pattern of IFN $\lambda$ receptor expression. The advent of less immunogenic and better tolerated IFNs together with individualized therapy suggests that IFNs will continue to play an important role in the future treatment of human disease.

\section{References and Notes}

1. Barral, P.M.; Sarkar, D.; Su, Z.Z.; Barber, G.N.; DeSalle, R.; Racaniello, V.R.; Fisher, P.B. Functions of the cytoplasmic RNA sensors RIG-I and MDA-5: key regulators of innate immunity. Pharmacol. Ther. 2009, 124, 219-234.

2. Tovey, M.G.; Lallemand, C.; Thyphronitis, G. Adjuvant activity of type I interferons. Biol. Chem. 2008, 389, 541-545.

3. Content, J. Mechanisms of induction and action of interferons. Verh. K Acad. Geneeskd. Belg. 2009, 71, 51-71.

4. Fensterl, V.; Sen, G.C. Interferons and viral infections. Biofactors 2009, 35, 14-20.

5. Takeuchi, O.; Matsushita, K.; Akira, S. Control of inflammatory responses by a novel RNase, Zc3h12a. Tanpakushitsu Kakusan Koso 2009, 54, 1837-1841.

6. Li, Y.; Batra, S.; Sassano, A.; Majchrzak, B.; Levy, D.E.; Gaestel, M.; Fish, E.N.; Davis, R.J.; Platanias, L.C. Activation of mitogen-activated protein kinase kinase (MKK) 3 and MKK6 by type I interferons. J. Biol. Chem. 2005, 280, 10001-10010.

7. Zoon, K.C.; Arnheiter, H.; Zur Nedden, D.; Fitzgerald, D.J.; Willingham, M.C. Human interferon alpha enters cells by receptor-mediated endocytosis. Virology 1983, 130, 195-203.

8. Lau, A.S.; Hannigan, G.E.; Freedman, M.H.; Williams, B.R. Regulation of interferon receptor expression in human blood lymphocytes in vitro and during interferon therapy. J. Clin. Invest. 1986, 77, 1632-1638.

9. Billard, C.; Ferbus, D.; Diez, R.A.; Kolb, J.P.; Mathiot, C.; Belanger, C.; Auzanneau, G.; Varet, B.; Falcoff, E.; Dumont, J. Correlation between the biological and therapeutic effects of interferon-alpha in low-grade nodular non-Hodgkin's lymphoma: lack of in vivo down-regulation and reduced affinity of IFN-alpha receptors in unresponsive patients. Leuk. Res. 1991, 15, 121-128. 
10. Oliver, B.; Mayorga, C.; Fernandez, V.; Leyva, L.; Leon, A.; Luque, G.; Lopez, J.C.; Tamayo, J.A.; Pinto-Medel, M.J.; de Ramon, E.; Blanco, E.; Alonso, A.; Fernandez, O. Interferon receptor expression in multiple sclerosis patients. J. Neuroimmunol. 2007, 183, 225-231.

11. Gilli, F.; Valentino, P.; Caldano, M.; Granieri, L.; Capobianco, M.; Malucchi, S.; Sala, A.; Marnetto, F.; Bertolotto, A. Expression and regulation of IFNalpha/beta receptor in IFNbetatreated patients with multiple sclerosis. Neurology 2008, 71, 1940-1947.

12. Cassel, S.L.; Rothman, P.B. Chapter 3: Role of SOCS in allergic and innate immune responses. Adv. Immunol. 2009, 103, 49-76.

13. Billiau, A.; Matthys, P. Interferon-gamma: a historical perspective. Cytokine Growth Factor Rev. 2009, 20, 97-113.

14. Chen, J.; Liu, X. The role of interferon gamma in regulation of CD4+ T-cells and its clinical implications. Cell Immunol. 2009, 254, 85-90.

15. Sheppard, P.; Kindsvogel, W.; Xu, W.; Henderson, K.; Schlutsmeyer, S.; Whitmore, T.E.; Kuestner, R.; Garrigues, U.; Birks, C.; Roraback, J.; Ostrander, C.; Dong, D.; Shin, J.; Presnell, S.; Fox, B.; Haldeman, B.; Cooper, E.; Taft, D.; Gilbert, T.; Grant, F.J.; Tackett, M.; Krivan, W.; McKnight, G.; Clegg, C.; Foster, D.; Klucher, K.M. IL-28, IL-29 and their class II cytokine receptor IL-28R. Nat. Immunol. 2003, 4, 63-68.

16. Kotenko, S.V.; Gallagher, G.; Baurin, V.V.; Lewis-Antes, A.; Shen, M.; Shah, N.K.; Langer, J.A.; Sheikh, F.; Dickensheets, H.; Donnelly, R.P. IFN-lambdas mediate antiviral protection through a distinct class II cytokine receptor complex. Nat. Immunol. 2003, 4, 69-77.

17. Gad, H.H.; Dellgren, C.; Hamming, O.J.; Vends, S.; Paludan, S.R.; Hartmann, R. Interferonlambda is functionally an interferon but structurally related to the interleukin-10 family. J. Biol. Chem. 2009, 284, 20869-20875.

18. de Veer, M.J.; Holko, M.; Frevel, M.; Walker, E.; Der, S.; Paranjape, J.M.; Silverman, R.H.; Williams, B.R. Functional classification of interferon-stimulated genes identified using microarrays. J. Leukoc. Biol. 2001, 69, 912-920.

19. Lallemand, C.; Blanchard, B.; Palmieri, M.; Lebon, P.; May, E.; Tovey, M.G. Single-stranded RNA viruses inactivate the transcriptional activity of p53 but induce NOXA-dependent apoptosis via post-translational modifications of IRF-1, IRF-3 and CREB. Oncogene 2007, 26, 328-338.

20. Steinman, R.M.; Hemmi, H. Dendritic cells: translating innate to adaptive immunity. Curr. Top. Microbiol. Immunol. 2006, 311, 17-58.

21. Le Bon, A.; Etchart, N.; Rossmann, C.; Ashton, M.; Hou, S.; Gewert, D.; Borrow, P.; Tough, D.F. Cross-priming of CD8+ T cells stimulated by virus-induced type I interferon. Nat. Immunol. 2003, 4, 1009-1015.

22. Le Bon, A.; Durand, V.; Kamphuis, E.; Thompson, C.; Bulfone-Paus, S.; Rossmann, C.; Kalinke, U.; Tough, D.F. Direct stimulation of T cells by type I IFN enhances the CD8+ T cell response during cross-priming. J. Immunol. 2006, 176, 4682-4689.

23. Beignon, A.S.; Skoberne, M.; Bhardwaj, N. Type I interferons promote cross-priming: more functions for old cytokines. Nat. Immunol. 2003, 4, 939-941.

24. Rogge, L.; D'Ambrosio, D.; Biffi, M.; Penna, G.; Minetti, L.J.; Presky, D.H.; Adorini, L.; Sinigaglia, F. The role of Stat4 in species-specific regulation of Th cell development by type I IFNs. J. Immunol. 1998, 161, 6567-6574. 
25. Gallagher, K.M.; Lauder, S.; Rees, I.W.; Gallimore, A.M.; Godkin, A.J. Type I interferon (IFN alpha) acts directly on human memory CD4+ T cells altering their response to antigen. J. Immunol. 2009, 183, 2915-2920.

26. Marrack, P.; Kappler, J.; Mitchell, T. Type I interferons keep activated T cells alive. J. Exp. Med. 1999, 189, 521-530.

27. Zhang, X.; Sun, S.; Hwang, I.; Tough, D.F.; Sprent, J. Potent and selective stimulation of memory-phenotype CD8+ T cells in vivo by IL-15. Immunity 1998, 8, 591-599.

28. Jego, G.; Palucka, A.K.; Blanck, J.P.; Chalouni, C.; Pascual, V.; Banchereau, J. Plasmacytoid dendritic cells induce plasma cell differentiation through type I interferon and interleukin 6. Immunity 2003, 19, 225-234.

29. Le Bon, A.; Schiavoni, G.; D'Agostino, G.; Gresser, I.; Belardelli, F.; Tough, D.F. Type i interferons potently enhance humoral immunity and can promote isotype switching by stimulating dendritic cells in vivo. Immunity 2001, 14, 461-470.

30. Kozlowski, A.; Charles, S.A.; Harris, J.M. Development of pegylated interferons for the treatment of chronic hepatitis C. BioDrugs 2001, 15, 419-429.

31. Harris, J.M.; Martin, N.E.; Modi, M. Pegylation: a novel process for modifying pharmacokinetics. Clin. Pharmacokinet. 2001, 40, 539-551.

32. McHutchison, J.G.; Lawitz, E.J.; Shiffman, M.L.; Muir, A.J.; Galler, G.W.; McCone, J.; Nyberg, L.M.; Lee, W.M.; Ghalib, R.H.; Schiff, E.R.; Galati, J.S.; Bacon, B.R.; Davis, M.N.; Mukhopadhyay, P.; Koury, K.; Noviello, S.; Pedicone, L.D.; Brass, C.A.; Albrecht, J.K.; Sulkowski, M.S. Peginterferon alfa-2b or alfa-2a with ribavirin for treatment of hepatitis C infection. N. Engl. J. Med. 2009, 361, 580-593.

33. Goverman, J. Autoimmune $\mathrm{T}$ cell responses in the central nervous system. Nat. Rev. Immunol. 2009, 9, 393-407.

34. Kiladjian, J.J.; Chomienne, C.; Fenaux, P. Interferon-alpha therapy in bcr-abl-negative myeloproliferative neoplasms. Leukemia 2008, 22, 1990-1998.

35. Tarhini, A.A.; Kirkwood, J.M. Clinical and immunologic basis of Interferon interferon therapy in melanoma. Ann. NY Acad. Sci. 2009, 47-57.

36. Sleijfer, S.; Bannink, M.; Van Gool, A.R.; Kruit, W.H.; Stoter, G. Side effects of interferon-alpha therapy. Pharm. World Sci. 2005, 27, 423-431.

37. Dinarello, C.A.; Bernheim, H.A.; Duff, G.W.; Le, H.V.; Nagabhushan, T.L.; Hamilton, N.C.; Coceani, F. Mechanisms of fever induced by recombinant human interferon. J. Clin. Invest. 1984, 74, 906-913.

38. Simin, M.; Brok, J.; Stimac, D.; Gluud, C.; Gluud, L.L. Cochrane systematic review: pegylated interferon plus ribavirin vs. interferon plus ribavirin for chronic hepatitis C. Aliment. Pharmacol. Ther. 2007, 25, 1153-1162.

39. Mira, J.A.; Lopez-Cortes, L.F.; Merino, D.; Arizcorreta-Yarza, A.; Rivero, A.; Collado, A.; RiosVillegas, M.J.; Gonzalez-Serrano, M.; Torres-Tortoso, M.; Macias, J.; Valera-Bestard, B.; Fernandez-Fuertes, E.; Giron-Gonzalez, J.A.; Lozano, F.; Pineda, J.A. Predictors of severe haematological toxicity secondary to pegylated interferon plus ribavirin treatment in HIV-HCVcoinfected patients. Antivir. Ther. 2007, 12, 1225-1235. 
40. Giron-Michel, J.; Weill, D.; Bailly, G.; Legras, S.; Nardeux, P.C.; Azzarone, B.; Tovey, M.G.; Eid, P. Direct signal transduction via functional interferon-alphabeta receptors in CD34+ hematopoietic stem cells. Leukemia 2002, 16, 1135-1142.

41. Mazur, E.M.; Richtsmeier, W.J.; South, K. Alpha-interferon: differential suppression of colony growth from human erythroid, myeloid, and megakaryocytic hematopoietic progenitor cells. $J$. Interferon Res. 1986, 6, 199-206.

42. Yamane, A.; Nakamura, T.; Suzuki, H.; Ito, M.; Ohnishi, Y.; Ikeda, Y.; Miyakawa, Y. Interferonalpha $2 \mathrm{~b}$-induced thrombocytopenia is caused by inhibition of platelet production but not proliferation and endomitosis in human megakaryocytes. Blood 2008, 112, 542-550.

43. Wada, M.; Marusawa, H.; Yamada, R.; Nasu, A.; Osaki, Y.; Kudo, M.; Nabeshima, M.; Fukuda, Y.; Chiba, T.; Matsuda, F. Association of genetic polymorphisms with interferon-induced haematologic adverse effects in chronic hepatitis C patients. J. Viral Hepat. 2009, 16, 388-396.

44. Meyer, O. Interferons and autoimmune disorders. Joint Bone Spine 2009, 76, 464-473.

45. Burdick, L.M.; Somani, N.; Somani, A.K. Type I IFNs and their role in the development of autoimmune diseases. Expert. Opin. Drug Saf. 2009, 8, 459-472.

46. Kyogoku, C.; Morinobu, A.; Nishimura, K.; Sugiyama, D.; Hashimoto, H.; Tokano, Y.; Mimori, T.; Terao, C.; Matsuda, F.; Kuno, T.; Kumagai, S. Lack of association between tyrosine kinase 2 (TYK2) gene polymorphisms and susceptibility to SLE in a Japanese population. Mod. Rheumatol. 2009, 19, 401-406.

47. Cunninghame Graham, D.S.; Akil, M.; Vyse, T.J. Association of polymorphisms across the tyrosine kinase gene, TYK2 in UK SLE families. Rheumatology (Oxford) 2007, 46, 927-930.

48. Suarez-Gestal, M.; Calaza, M.; Dieguez-Gonzalez, R.; Perez-Pampin, E.; Pablos, J.L.; Navarro, F.; Narvaez, J.; Marenco, J.L.; Herrero-Beaumont, G.; Fernandez-Gutierrez, B.; Lamas, J.R.; de la Serna, A.R.; Ortiz, A.M.; Carreno, L.; Canete, J.D.; Caliz, R.; Blanco, F.J.; Balsa, A.; GomezReino, J.J.; Gonzalez, A. Rheumatoid arthritis does not share most of the newly identified systemic lupus erythematosus genetic factors. Arthritis Rheum. 2009, 60, 2558-2564.

49. Suarez-Gestal, M.; Calaza, M.; Endreffy, E.; Pullmann, R.; Ordi-Ros, J.; Domenico Sebastiani, G.; Ruzickova, S.; Jose Santos, M.; Papasteriades, C.; Marchini, M.; Skopouli, F.N.; Suarez, A.; Blanco, F.J.; D'Alfonso, S.; Bijl, M.; Carreira, P.; Witte, T.; Migliaresi, S.; Gomez-Reino, J.J.; Gonzalez, A. Replication of recently identified systemic lupus erythematosus genetic associations: a case-control study. Arthritis Res. Ther. 2009, 11, R69.

50. Graham, R.R.; Kozyrev, S.V.; Baechler, E.C.; Reddy, M.V.; Plenge, R.M.; Bauer, J.W.; Ortmann, W.A.; Koeuth, T.; Gonzalez Escribano, M.F.; Pons-Estel, B.; Petri, M.; Daly, M.; Gregersen, P.K.; Martin, J.; Altshuler, D.; Behrens, T.W.; Alarcon-Riquelme, M.E. A common haplotype of interferon regulatory factor 5 (IRF5) regulates splicing and expression and is associated with increased risk of systemic lupus erythematosus. Nat. Genet. 2006, 38, 550-555.

51. Hellquist, A.; Jarvinen, T.M.; Koskenmies, S.; Zucchelli, M.; Orsmark-Pietras, C.; Berglind, L.; Panelius, J.; Hasan, T.; Julkunen, H.; D'Amato, M.; Saarialho-Kere, U.; Kere, J. Evidence for genetic association and interaction between the TYK2 and IRF5 genes in systemic lupus erythematosus. J. Rheumatol. 2009, 36, 1631-1638.

52. Miceli-Richard, C.; Gestermann, N.; Ittah, M.; Comets, E.; Loiseau, P.; Puechal, X.; Hachulla, E.; Gottenberg, J.E.; Lebon, P.; Becquemont, L.; Mariette, X. The CGGGG insertion/deletion 
polymorphism of the IRF5 promoter is a strong risk factor for primary Sjogren's syndrome. Arthritis Rheum. 2009, 60, 1991-1997.

53. Miceli-Richard, C.; Comets, E.; Loiseau, P.; Puechal, X.; Hachulla, E.; Mariette, X. Association of an IRF5 gene functional polymorphism with Sjogren's syndrome. Arthritis Rheum. 2007, 56, 3989-3994.

54. Nordmark, G.; Kristjansdottir, G.; Theander, E.; Eriksson, P.; Brun, J.G.; Wang, C.; Padyukov, L.; Truedsson, L.; Alm, G.; Eloranta, M.L.; Jonsson, R.; Ronnblom, L.; Syvanen, A.C. Additive effects of the major risk alleles of IRF5 and STAT4 in primary Sjogren's syndrome. Genes Immun. 2009, 10, 68-76.

55. Kawaguchi, Y.; Ota, Y.; Kawamoto, M.; Ito, I.; Tsuchiya, N.; Sugiura, T.; Katsumata, Y.; Soejima, M.; Sato, S.; Hasegawa, M.; Fujimoto, M.; Takehara, K.; Kuwana, M.; Yamanaka, H.; Hara, M. Association study of a polymorphism of the CTGF gene and susceptibility to systemic sclerosis in the Japanese population. Ann. Rheum. Dis. 2009, 68, 1921-1924.

56. Wenzel, J.; Zahn, S.; Bieber, T.; Tuting, T. Type I interferon-associated cytotoxic inflammation in cutaneous lupus erythematosus. Arch. Dermatol. Res. 2009, 301, 83-86.

57. Yilmaz, S.; Cimen, K.A. Pegylated interferon alpha-2B induced lupus in a patient with chronic hepatitis B virus infection: case report. Clin. Rheumatol. 2009, 28, 1241-1243.

58. Bennett, L.; Palucka, A.K.; Arce, E.; Cantrell, V.; Borvak, J.; Banchereau, J.; Pascual, V. Interferon and granulopoiesis signatures in systemic lupus erythematosus blood. J. Exp. Med. 2003, 197, 711-723.

59. Ronnblom, L.; Eloranta, M.L.; Alm, G.V. The type I interferon system in systemic lupus erythematosus. Arthritis Rheum. 2006, 54, 408-420.

60. Baechler, E.C.; Batliwalla, F.M.; Karypis, G.; Gaffney, P.M.; Ortmann, W.A.; Espe, K.J.; Shark, K.B.; Grande, W.J.; Hughes, K.M.; Kapur, V.; Gregersen, P.K.; Behrens, T.W. Interferoninducible gene expression signature in peripheral blood cells of patients with severe lupus. Proc. Natl. Acad. Sci. USA 2003, 100, 2610-2615.

61. Kariuki, S.N.; Kirou, K.A.; MacDermott, E.J.; Barillas-Arias, L.; Crow, M.K.; Niewold, T.B. Cutting edge: autoimmune disease risk variant of STAT4 confers increased sensitivity to IFNalpha in lupus patients in vivo. J. Immunol. 2009, 182, 34-38.

62. Farkas, L.; Beiske, K.; Lund-Johansen, F.; Brandtzaeg, P.; Jahnsen, F.L. Plasmacytoid dendritic cells (natural interferon- alpha/beta-producing cells) accumulate in cutaneous lupus erythematosus lesions. Am. J. Pathol. 2001, 159, 237-243.

63. Blomberg, S.; Eloranta, M.L.; Cederblad, B.; Nordlin, K.; Alm, G.V.; Ronnblom, L. Presence of cutaneous interferon-alpha producing cells in patients with systemic lupus erythematosus. Lupus 2001, 10, 484-490.

64. Schaefer, M.; Engelbrecht, M.A.; Gut, O.; Fiebich, B.L.; Bauer, J.; Schmidt, F.; Grunze, H.; Lieb, K. Interferon alpha (IFNalpha) and psychiatric syndromes: a review. Prog. Neuropsychopharmacol. Biol. Psychiatry 2002, 26, 731-746.

65. Unoki, H.; Moriyama, A.; Tabaru, A.; Masumoto, A.; Otsuki, M. Development of Sjogren's syndrome during treatment with recombinant human interferon-alpha-2b for chronic hepatitis $\mathrm{C}$. $J$. Gastroenterol. 1996, 31, 723-727. 
66. De Santi, L.; Costantini, M.C.; Annunziata, P. Long time interval between multiple sclerosis onset and occurrence of primary Sjogren's syndrome in a woman treated with interferon-beta. Acta Neurol. Scand. 2005, 112, 194-196.

67. Nikolov, N.P.; Illei, G.G. Pathogenesis of Sjogren's syndrome. Curr. Opin. Rheumatol. 2009, 21, 465-470.

68. Perl, A. Emerging new pathways of pathogenesis and targets for treatment in systemic lupus erythematosus and Sjogren's syndrome. Curr. Opin. Rheumatol. 2009, 21, 443-447.

69. Gottenberg, J.E.; Cagnard, N.; Lucchesi, C.; Letourneur, F.; Mistou, S.; Lazure, T.; Jacques, S.; Ba, N.; Ittah, M.; Lepajolec, C.; Labetoulle, M.; Ardizzone, M.; Sibilia, J.; Fournier, C.; Chiocchia, G.; Mariette, X. Activation of IFN pathways and plasmacytoid dendritic cell recruitment in target organs of primary Sjogren's syndrome. Proc. Natl. Acad. Sci. USA 2006, 103, 2770-2775.

70. Lovgren, T.; Eloranta, M.L.; Kastner, B.; Wahren-Herlenius, M.; Alm, G.V.; Ronnblom, L. Induction of interferon-alpha by immune complexes or liposomes containing systemic lupus erythematosus autoantigen- and Sjogren's syndrome autoantigen-associated RNA. Arthritis Rheum. 2006, 54, 1917-1927.

71. Wakamatsu, E.; Matsumoto, I.; Yasukochi, T.; Naito, Y.; Goto, D.; Mamura, M.; Ito, S.; Tsutsumi, A.; Sumida, T. Overexpression of phosphorylated STAT-1alpha in the labial salivary glands of patients with Sjogren's syndrome. Arthritis Rheum. 2006, 54, 3476-3484.

72. Ito, I.; Kawaguchi, Y.; Kawasaki, A.; Hasegawa, M.; Ohashi, J.; Hikami, K.; Kawamoto, M.; Fujimoto, M.; Takehara, K.; Sato, S.; Hara, M.; Tsuchiya, N. Association of a functional polymorphism in the IRF5 region with systemic sclerosis in a Japanese population. Arthritis Rheum. 2009, 60, 1845-1850.

73. Cummins, M.J.; Papas, A.; Kammer, G.M.; Fox, P.C. Treatment of primary Sjogren's syndrome with low-dose human interferon alfa administered by the oromucosal route: combined phase III results. Arthritis Rheum. 2003, 49, 585-593.

74. Streckfus, C.; Bigler, L.; Navazesh, M.; Al-Hashimi, I. Cytokine concentrations in stimulated whole saliva among patients with primary Sjogren's syndrome, secondary Sjogren's syndrome, and patients with primary Sjogren's syndrome receiving varying doses of interferon for symptomatic treatment of the condition: a preliminary study. Clin. Oral Investig. 2001, 5, 133-135.

75. Yamada, S.; Mori, K.; Matsuo, K.; Inukai, A.; Kawagashira, Y.; Sobue, G. Interferon alfa treatment for Sjogren's syndrome associated neuropathy. J. Neurol. Neurosurg. Psychiatry 2005, 76, 576-578.

76. Khurshudian, A.V. A pilot study to test the efficacy of oral administration of interferon-alpha lozenges to patients with Sjogren's syndrome. Oral Surg. Oral Med. Oral Pathol. Oral Radiol. Endod. 2003, 95, 38-44.

77. Shiozawa, S.; Cummins, J.M.; Fox, P.C. Opening the Flood Gates: Interferon-alpha Treatment for Sjogren's Syndrome. BioDrugs 2000, 13, 305-311.

78. Ferraccioli, G.F.; Salaffi, F.; De Vita, S.; Casatta, L.; Avellini, C.; Carotti, M.; Beltrami, C.A.; Cervini, C.; Bartoli, E. Interferon alpha-2 (IFN alpha 2) increases lacrimal and salivary function in Sjogren's syndrome patients. Preliminary results of an open pilot trial versus $\mathrm{OH}$-chloroquine. Clin. Exp. Rheumatol. 1996, 14, 367-371. 
79. Shiozawa, S.; Morimoto, I.; Tanaka, Y.; Shiozawa, K. A preliminary study on the interferon-alpha treatment for xerostomia of Sjogren's syndrome. Br. J. Rheumatol. 1993, 32, 52-54.

80. Walsh, R.J.; Kong, S.W.; Yao, Y.; Jallal, B.; Kiener, P.A.; Pinkus, J.L.; Beggs, A.H.; Amato, A.A.; Greenberg, S.A. Type I interferon-inducible gene expression in blood is present and reflects disease activity in dermatomyositis and polymyositis. Arthritis Rheum. 2007, 56, 3784-3792.

81. Baechler, E.C.; Bauer, J.W.; Slattery, C.A.; Ortmann, W.A.; Espe, K.J.; Novitzke, J.; Ytterberg, S.R.; Gregersen, P.K.; Behrens, T.W.; Reed, A.M. An interferon signature in the peripheral blood of dermatomyositis patients is associated with disease activity. Mol. Med. 2007, 13, 59-68.

82. Somani, A.K.; Swick, A.R.; Cooper, K.D.; McCormick, T.S. Severe dermatomyositis triggered by interferon beta-1a therapy and associated with enhanced type I interferon signaling. Arch. Dermatol. 2008, 144, 1341-1349.

83. Dietrich, L.L.; Bridges, A.J.; Albertini, M.R. Dermatomyositis after interferon alpha treatment. Med. Oncol. 2000, 17, 64-69.

84. Dieude, P.; Guedj, M.; Wipff, J.; Ruiz, B.; Hachulla, E.; Diot, E.; Granel, B.; Sibilia, J.; Tiev, K.; Mouthon, L.; Cracowski, J.L.; Carpentier, P.H.; Amoura, Z.; Fajardy, I.; Avouac, J.; Meyer, O.; Kahan, A.; Boileau, C.; Allanore, Y. STAT4 is a genetic risk factor for systemic sclerosis having additive effects with IRF5 on disease susceptibility and related pulmonary fibrosis. Arthritis Rheum. 2009, 60, 2472-2479.

85. Rueda, B.; Broen, J.; Simeon, C.; Hesselstrand, R.; Diaz, B.; Suarez, H.; Ortego-Centeno, N.; Riemekasten, G.; Fonollosa, V.; Vonk, M.C.; van den Hoogen, F.H.; Sanchez-Roman, J.; AguirreZamorano, M.A.; Garcia-Portales, R.; Pros, A.; Camps, M.T.; Gonzalez-Gay, M.A.; Coenen, M.J.; Airo, P.; Beretta, L.; Scorza, R.; van Laar, J.; Gonzalez-Escribano, M.F.; Nelson, J.L.; Radstake, T.R.; Martin, J. The STAT4 gene influences the genetic predisposition to systemic sclerosis phenotype. Hum. Mol. Genet. 2009, 18, 2071-2077.

86. Powell, A.; Myles, M.L.; Yacyshyn, E. The development of systemic sclerosis in a female patient with multiple sclerosis following beta interferon treatment. Clin. Rheumatol. 2008, 27, 1467-1468.

87. Stubgen, J.P. Interferon alpha and neuromuscular disorders. J Neuroimmunol 2009, 207, 3-17.

88. Alsalameh, S.; Manger, B.; Kern, P.; Kalden, J. New onset of rheumatoid arthritis during interferon beta-1B treatment in a patient with multiple sclerosis: comment on the case report by Jabaily and Thompson. Arthritis Rheum. 1998, 41, 754.

89. Levesque, M.C.; Ward, F.E.; Jeffery, D.R.; Weinberg, J.B. Interferon-beta1A-induced polyarthritis in a patient with the HLA-DRB1*0404 allele. Arthritis Rheum. 1999, 42, 569-573.

90. Gota, C.; Calabrese, L. Induction of clinical autoimmune disease by therapeutic interferon-alpha. Autoimmunity 2003, 36, 511-518.

91. Han, S.W.; Lee, W.K.; Kwon, K.T.; Lee, B.K.; Nam, E.J.; Kim, G.W. Association of polymorphisms in interferon regulatory factor 5 gene with rheumatoid arthritis: a metaanalysis. $J$. Rheumatol. 2009, 36, 693-697.

92. Fabris, P.; Floreani, A.; Tositti, G.; Vergani, D.; De Lalla, F.; Betterle, C. Type 1 diabetes mellitus in patients with chronic hepatitis $\mathrm{C}$ before and after interferon therapy. Aliment. Pharmacol. Ther. 2003, 18, 549-558. 
93. Huang, X.; Yuang, J.; Goddard, A.; Foulis, A.; James, R.F.; Lernmark, A.; Pujol-Borrell, R.; Rabinovitch, A.; Somoza, N.; Stewart, T.A. Interferon expression in the pancreases of patients with type I diabetes. Diabetes 1995, 44, 658-664.

94. Huang, X.; Hultgren, B.; Dybdal, N.; Stewart, T.A. Islet expression of interferon-alpha precedes diabetes in both the BB rat and streptozotocin-treated mice. Immunity 1994, 1, 469-478.

95. Stewart, T.A.; Hultgren, B.; Huang, X.; Pitts-Meek, S.; Hully, J.; MacLachlan, N.J. Induction of type I diabetes by interferon-alpha in transgenic mice. Science 1993, 260, 1942-1946.

96. Heathcote, E.J. Autoimmune hepatitis and chronic hepatitis C: latent or initiated by interferon therapy? Gastroenterology 1995, 108, 1942-1944.

97. Duchini, A. Autoimmune hepatitis and interferon beta-1a for multiple sclerosis. Am. J. Gastroenterol. 2002, 97, 767-768.

98. Lebiedz, P.; August, C.; Domschke, W.; Schmidt, H.H. Interferon (IFN) for malignant melanoma unmasking an autoimmune hepatitis. Eur. J. Intern. Med. 2009, 20, e3-4.

99. Coriat, R.; Podevin, P. Fulminant autoimmune hepatitis after successful interferon treatment in an HIV-HCV co-infected patient. Int. J. STD. AIDS 2008, 19, 208-210.

100. Pulicken, M.; Koteish, A.; DeBusk, K.; Calabresi, P.A. Unmasking of autoimmune hepatitis in a patient with MS following interferon beta therapy. Neurology 2006, 66, 1954-1955.

101. von Kalckreuth, V.; Lohse, A.W.; Schramm, C. Unmasking autoimmune hepatitis under immunomodulatory treatment of multiple sclerosis--not only beta interferon. Am J Gastroenterol 2008, 103, 2147-2148; author reply 2148.

102. Vispo, E.; Maida, I.; Moreno, A.; Barreiro, P.; Soriano, V. Autoimmune hepatitis induced by pegylated interferon in an HIV-infected patient with chronic hepatitis C. J. Antimicrob. Chemother. 2008, 62, 1470-1472.

103. Valentine, A.D.; Meyers, C.A.; Kling, M.A.; Richelson, E.; Hauser, P. Mood and cognitive side effects of interferon-alpha therapy. Semin. Oncol. 1998, 25, 39-47.

104. Dafny, N.; Yang, P.B. Interferon and the central nervous system. Eur. J. Pharmacol. 2005, 523, 1-15.

105. Capuron, L.; Miller, A.H. Cytokines and psychopathology: lessons from interferon-alpha. Biol. Psychiatry 2004, 56, 819-824.

106. Wichers, M.C.; Koek, G.H.; Robaeys, G.; Verkerk, R.; Scharpe, S.; Maes, M. IDO and interferon-alpha-induced depressive symptoms: a shift in hypothesis from tryptophan depletion to neurotoxicity. Mol. Psychiatry 2005, 10, 538-544.

107. Suzuki, E.; Yagi, G.; Nakaki, T.; Kanba, S.; Asai, M. Elevated plasma nitrate levels in depressive states. J. Affect. Disord. 2001, 63, 221-224.

108. Schaefer, M.; Schwaiger, M.; Pich, M.; Lieb, K.; Heinz, A. Neurotransmitter changes by interferon-alpha and therapeutic implications. Pharmacopsychiatry 2003, 36 (Suppl. 3), S203-S206.

109. Wichers, M.C.; Kenis, G.; Leue, C.; Koek, G.; Robaeys, G.; Maes, M. Baseline immune activation as a risk factor for the onset of depression during interferon-alpha treatment. Biol. Psychiatry 2006, 60, 77-79.

110. Bonaccorso, S.; Puzella, A.; Marino, V.; Pasquini, M.; Biondi, M.; Artini, M.; Almerighi, C.; Levrero, M.; Egyed, B.; Bosmans, E.; Meltzer, H.Y.; Maes, M. Immunotherapy with interferon- 
alpha in patients affected by chronic hepatitis $\mathrm{C}$ induces an intercorrelated stimulation of the cytokine network and an increase in depressive and anxiety symptoms. Psychiatry Res. 2001, 105, 45-55.

111. Bull, S.J.; Huezo-Diaz, P.; Binder, E.B.; Cubells, J.F.; Ranjith, G.; Maddock, C.; Miyazaki, C.; Alexander, N.; Hotopf, M.; Cleare, A.J.; Norris, S.; Cassidy, E.; Aitchison, K.J.; Miller, A.H.; Pariante, C.M. Functional polymorphisms in the interleukin-6 and serotonin transporter genes, and depression and fatigue induced by interferon-alpha and ribavirin treatment. Mol. Psychiatry 2009, 14, 1145.

112. Hirsch, M.; Knight, J.; Tobita, M.; Soltys, J.; Panitch, H.; Mao-Draayer, Y. The effect of interferon-beta on mouse neural progenitor cell survival and differentiation. Biochem. Biophys. Res. Commun. 2009, 388, 181-186.

113. Fattovich, G.; Giustina, G.; Favarato, S.; Ruol, A. A survey of adverse events in 11,241 patients with chronic viral hepatitis treated with alfa interferon. J. Hepatol. 1996, 24, 38-47.

114. Uyama, E.; Fujiki, N.; Uchino, M. Exacerbation of myasthenia gravis during interferon-alpha treatment. J. Neurol. Sci. 1996, 144, 221-222.

115. Oishi, A.; Miyamoto, K.; Kashii, S.; Yoshimura, N. Retinopathy is not the only ocular symptom: myasthenia gravis in association with interferon therapy. Br. J. Ophthalmol. 2005, 89, 1542-1543.

116. Mizoi, Y.; Kaneko, H.; Oharazawa, A.; Kuroiwa, H. [Parkinsonism in a patient receiving interferon alpha therapy for chronic hepatitis C]. Rinsho. Shinkeigaku 1997, 37, 54-56.

117. Almeida, C.M.; Galvao Mde, L.; Ferreira, P.L.; Braga, W.S. Interferon-induced Parkinsonism in a patient with chronic hepatitis C. Arq. Neuropsiquiatr. 2009, 67, 715-716.

118. Shuto, H.; Kataoka, Y.; Horikawa, T.; Fujihara, N.; Oishi, R. Repeated interferon-alpha administration inhibits dopaminergic neural activity in the mouse brain. Brain Res. 1997, 747, 348-351.

119. Monzani, F.; Caraccio, N.; Dardano, A.; Ferrannini, E. Thyroid autoimmunity and dysfunction associated with type I interferon therapy. Clin. Exp. Med. 2004, 3, 199-210.

120. Roti, E.; Minelli, R.; Giuberti, T.; Marchelli, S.; Schianchi, C.; Gardini, E.; Salvi, M.; Fiaccadori, F.; Ugolotti, G.; Neri, T.M.; Braverman, L.E. Multiple changes in thyroid function in patients with chronic active HCV hepatitis treated with recombinant interferon-alpha. Am. J. Med. 1996, 101, 482-487.

121. Froidure, A.; Horsmans, Y.; Lefebvre, C. Multisystemic sarcoidosis associated with a second therapy for chronic hepatitis C. Acta Gastroenterol. Belg. 2009, 72, 249-251.

122. Bolukbas, C.; Bolukbas, F.F.; Kebdir, T.; Canayaz, L.; Dalay, A.R.; Kilic, G.; Ovunc, O. Development of sarcoidosis during interferon alpha $2 \mathrm{~b}$ and ribavirin combination therapy for chronic hepatitis C--a case report and review of the literature. Acta Gastroenterol. Belg. 2005, 68, 432-434.

123. Benali, S.; Boustiere, C.; Castellani, P.; Cesari, C.; Jullien, M.; Lecomte, L.; Lebars, O.; Lambot, G.; Loyer, R.; Masseboeuf, A.; Perrier, H.; Oules, V.; Bourliere, M. Sarcoidosis following pegylated interferon therapy: two cases. Gastroenterol. Clin. Biol. 2006, 30, 615-619.

124. Ubina-Aznar, E.; Fernandez-Moreno, N.; Rivera-Irigoin, R.; Navarro-Jarabo, J.M.; GarciaFernandez, G.; Perez-Aisa, A.; Vera-Rivero, F.; Fernandez-Perez, F.; Moreno-Mejias, P.; Mendez-Sanchez, I.; de Sola-Earle, C.; Sanchez-Cantos, A. Pulmonary sarcoidosis associated 
with pegylated interferon in the treatment of chronic hepatitis C. Gastroenterol. Hepatol. 2005, 28, 450-452.

125. Hoffmann, R.M.; Jung, M.C.; Motz, R.; Gossl, C.; Emslander, H.P.; Zachoval, R.; Pape, G.R. Sarcoidosis associated with interferon-alpha therapy for chronic hepatitis C. J. Hepatol. 1998, 28, 1058-1063.

126. Pietropaoli, A.; Modrak, J.; Utell, M. Interferon-alpha therapy associated with the development of sarcoidosis. Chest 1999, 116, 569-572.

127. Alfageme Michavila, I.; Merino Sanchez, M.; Perez Ronchel, J.; Lara Lara, I.; Suarez Garcia, E.; Lopez Garrido, J. Sarcoidosis following combined ribavirin and interferon therapy: a case report and review of the literature. Arch. Bronconeumol. 2004, 40, 45-49.

128. Suppiah, V.; Moldovan, M.; Ahlenstiel, G.; Berg, T.; Weltman, M.; Abate, M.L.; Bassendine, M.; Spengler, U.; Dore, G.J.; Powell, E.; Riordan, S.; Sheridan, D.; Smedile, A.; Fragomeli, V.; Muller, T.; Bahlo, M.; Stewart, G.J.; Booth, D.R.; George, J. IL28B is associated with response to chronic hepatitis $\mathrm{C}$ interferon-alpha and ribavirin therapy. Nat. Genet. 2009, 41, 1100-1104.

129. Ge, D.; Fellay, J.; Thompson, A.J.; Simon, J.S.; Shianna, K.V.; Urban, T.J.; Heinzen, E.L.; Qiu, P.; Bertelsen, A.H.; Muir, A.J.; Sulkowski, M.; McHutchison, J.G.; Goldstein, D.B. Genetic variation in IL28B predicts hepatitis C treatment-induced viral clearance. Nature 2009, 461, 399-401.

130. Tanaka, Y.; Nishida, N.; Sugiyama, M.; Kurosaki, M.; Matsuura, K.; Sakamoto, N.; Nakagawa, M.; Korenaga, M.; Hino, K.; Hige, S.; Ito, Y.; Mita, E.; Tanaka, E.; Mochida, S.; Murawaki, Y.; Honda, M.; Sakai, A.; Hiasa, Y.; Nishiguchi, S.; Koike, A.; Sakaida, I.; Imamura, M.; Ito, K.; Yano, K.; Masaki, N.; Sugauchi, F.; Izumi, N.; Tokunaga, K.; Mizokami, M. Genome-wide association of IL28B with response to pegylated interferon-alpha and ribavirin therapy for chronic hepatitis C. Nat. Genet. 2009, 41, 1105-1109.

131. Marcello , T.; Grakoui, A.; Barba-Spaeth, G.; Machlin, E.; Kotenko, S.; MacDonald, M.; Rice, C. Interferons alpha and lambda inhibit hepatitis $\mathrm{C}$ virus replication with distinct signal transduction and gene regulation kinetic. Gastroenterology 2006, 131, 1887-1898.

132. Miller, D.M.; Klucher, K.M.; Freeman, J.A.; Hausman, D.F.; Fontana, D.; Williams, D.E. Interferon Lambda as a potential new therapeutic for hepatitis C. Ann. NY Acad. Sci. 2009, 1182, 80-87.

133. Donnelly, R.P.; Sheikh, F.; Kotenko, S.V.; Dickensheets, H. The expanded family of class II cytokines that share the IL-10 receptor-2 (IL-10R2) chain. J. Leukoc. Biol. 2004, 76, 314-321.

134. Sheikh, F.; Baurin, V.V.; Lewis-Antes, A.; Shah, N.K.; Smirnov, S.V.; Anantha, S.; Dickensheets, H.; Dumoutier, L.; Renauld, J.C.; Zdanov, A.; Donnelly, R.P.; Kotenko, S.V. Cutting edge: IL-26 signals through a novel receptor complex composed of IL-20 receptor 1 and IL-10 receptor 2. J. Immunol. 2004, 172, 2006-2010.

135. Schoenborn, J.R.; Wilson, C.B. Regulation of interferon-gamma during innate and adaptive immune responses. Adv. Immunol. 2007, 96, 41-101.

136. Czarniecki, C.W.; Sonnenfeld, G. The Interferons: Characterization and Application; John Wiley and Sons Inc.: Hoboken, NJ, USA, 2006; pp.309-336. 
137. Shapiro, F.; Glimcher, M.J.; Holtrop, M.E.; Tashjian, A.H., Jr.; Brickley-Parsons, D.; Kenzora, J.E. Human osteopetrosis: a histological, ultrastructural, and biochemical study. J. Bone Joint Surg. Am. 1980, 62, 384-399.

138. Miller, C.H.T.; Maher, S.G.; Young, H.A. Clinical use of Interferon-gamma. Ann. N. Y. Acad. Sci. 2009, 1182, 69-79.

139. Machold, K.P.; Smolen, J.S. Interferon-gamma induced exacerbation of systemic lupus erythematosus. J. Rheumatol. 1990, 17, 831-832.

140. Graninger, W.B.; Hassfeld, W.; Pesau, B.B.; Machold, K.P.; Zielinski, C.C.; Smolen, J.S. Induction of systemic lupus erythematosus by interferon-gamma in a patient with rheumatoid arthritis. J. Rheumatol. 1991, 18, 1621-1622.

141. Fukami, T.; Miyazaki, E.; Matsumoto, T.; Kumamoto, T.; Tsuda, T. Elevated expression of interleukin-18 in the granulomatous lesions of muscular sarcoidosis. Clin. Immunol. 2001, 101, $12-20$.

142. Shigehara, K.; Shijubo, N.; Ohmichi, M.; Takahashi, R.; Kon, S.; Okamura, H.; Kurimoto, M.; Hiraga, Y.; Tatsuno, T.; Abe, S.; Sato, N. IL-12 and IL-18 are increased and stimulate IFNgamma production in sarcoid lungs. J. Immunol. 2001, 166, 642-649.

143. Hamzaoui, A.; Ghrairi, H.; Ammar, J.; Zekri, S.; Guemira, F.; Hamzaoui, K. IL-18 mRNA expression and IFN-gamma induction in bronchoalveolar lavage from Behcet's disease. Clin. Exp. Rheumatol. 2003, 21, S8-S14.

144. Sugiyama, K.; Mukae, H.; Ishii, H.; Kakugawa, T.; Ishimoto, H.; Nakayama, S.; Shirai, R.; Fujii, T.; Mizuta, Y.; Kohno, S. Elevated levels of interferon gamma-inducible protein-10 and epithelial neutrophil-activating peptide-78 in patients with pulmonary sarcoidosis. Respirology 2006, 11, 708-714.

145. Takeuchi, M.; Oh, I.K.; Suzuki, J.; Hattori, T.; Takeuchi, A.; Okunuki, Y.; Usui, Y.; Usui, M. Elevated serum levels of CXCL9/monokine induced by interferon-gamma and CXCL10/interferon-gamma-inducible protein-10 in ocular sarcoidosis. Invest. Ophthalmol. Vis. Sci. 2006, 47, 1063-1068.

146. Wandl, U.B.; Kloke, O.; Nagel-Hiemke, M.; Moritz, T.; Becher, R.; Opalka, B.; Holtkamp, W.; Bartels, H.; Seeber, S.; Niederle, N. Combination therapy with interferon alpha-2b plus low-dose interferon gamma in pretreated patients with $\mathrm{Ph}$-positive chronic myelogenous leukaemia. Br. $J$. Haematol. 1992, 81, 516-519.

147. Deisenhammer, F. Neutralizing antibodies to interferon-beta and other immunological treatments for multiple sclerosis: prevalence and impact on outcomes. CNS Drugs 2009, 23, 379-396.

148. Cohen, B.A.; Oger, J.; Gagnon, A.; Giovannoni, G. The implications of immunogenicity for protein-based multiple sclerosis therapies. J. Neurol. Sci. 2008, 275, 7-17.

149. Antonelli, G.; Giannelli, G.; Currenti, M.; Simeoni, E.; Del Vecchio, S.; Maggi, F.; Pistello, M.; Roffi, L.; Pastore, G.; Chemello, L.; Dianzani, F. Antibodies to interferon (IFN) in hepatitis C patients relapsing while continuing recombinant IFN-alpha2 therapy. Clin. Exp. Immunol. 1996, 104, 384-387.

150. Karnam, U.S.; Reddy, K.R. Pegylated interferons. Clin. Liver Dis. 2003, 7, 139-148.

151. Luxon, B.A.; Grace, M.; Brassard, D.; Bordens, R. Pegylated interferons for the treatment of chronic hepatitis C infection. Clin. Ther. 2002, 24, 1363-1383. 
152. Jorns, C.; Holzinger, D.; Thimme, R.; Spangenberg, H.C.; Weidmann, M.; Rasenack, J.; Blum, H.E.; Haller, O.; Kochs, G. Rapid and simple detection of IFN-neutralizing antibodies in chronic hepatitis C non-responsive to IFN-alpha. J. Med. Virol. 2006, 78, 74-82.

153. Antonelli, G. In vivo development of antibody to interferons: an update to 1996. J. Interferon Cytokine Res. 1997, 17 Suppl 1, S39-46.

154. Hartung, H.; Polman, C.; Bertolotto, A.; Deisenhammer, F.; Giovannoni, G.; E., H.; Hemmer, B.; Hillert J; Kappos L; Kieseier B; Killestein J, M.C.; Comabella M; Pachner A; Schellekens H; Sellebjerg F; Selmaj K; PS., S. Neutralising antibodies to interferon beta in multiple sclerosis : expert panel report. J. Neurol. Neurosurg. Psychiatry 2007, 254, 827-837.

155. Sauerborn, M.B., V. Jiskoot, W. Schellekens, H. Immunological mechanism underlying the immune response to recombinant human protein therapeutics. Trends Pharmacol. Sci. 2009, 31, 53-59.

156. Cohen, B.; Oger, J.; Gagnon, A.; Giovannoni, G. The implications of immunogenicity for protein-based multiple sclerosis therapies. J. Neurol. Sci. 2008, 275, 7-17.

157. Lallemand, C.; Meritet, J.F.; Erickson, R.; Grossberg, S.E.; Roullet, E.; Lyon-Caen, O.; Lebon, P.; Tovey, M.G. Quantification of neutralizing antibodies to human type I interferons using division-arrested frozen cells carrying an interferon-regulated reporter-gene. J. Interferon Cytokine Res. 2008, 28, 393-404.

158. Casadevall, N.; Nataf, J.; Viron, B.; Kolta, A.; Kiladjian, J.; Martin-Dupont, P.; Michaud, P., Papo, T.; Ugo, V.; Teyssandier, I.; Varet, B.; P., M. Pure red-cell aplasia and antierythropoietin antibodies in patients treated with recombinant erythropoietin. N. Engl. J. Med. 2002, 346, 469-475.

159. Neumann, T.A.; Foote, M. Megakaryocyte growth and development factor (MGDF): an Mpl ligand and cytokine that regulates thrombopoiesis. Cytokines Cell. Mol. Ther. 2000, 6, 47-56.

160. Namaka, M.; Pollitt-Smith, M.; Gupta, A.; Klowak, M.; Vasconcelos, M.; Turcotte, D.; Gong, Y.; Melanson, M. The clinical importance of neutralizing antibodies in relapsing-remitting multiple sclerosis. Curr. Med. Res. Opin. 2006, 22, 223-239.

161. Noronha, A. Neutralizing antibodies to interferon. Neurology 2007, 68, S16-S22.

162. Jaffe, H.; Chen, A.; Kramer, S.; Sherwin, S. The absence of interferon antibody formation in patients receiving recombinant human interferon-gamma. J. Biol. Response Mod. 1987, 6, 576-580.

163. Tanaka, Y.; Hori, T.; Ito, K.; Fujita, T.; Ishikawa, T.; Uchiyama, T. Disseminated Mycobacterium avium complex infection in a patient with autoantibody to interferon-gamma. Intern. Med. 2007, 46, 1005-1009.

164. Patel, S.; Ding, L.; Brown, M.; Lantz, L.; Gay, T.; Cohen, S.; Martyak, L.; Kubak, B.; Holland, S. Anti-IFN-gamma autoantibodies in disseminated nontuberculous mycobacterial infections. $J$. Immunol. 2005, 175, 4769-4776.

165. Kampmann, B.; Hemingway, C.S., A.; Davidson, R.; Goodsall, A.; Anderson, S.; Nicol, M.; Schölvinck, E.; Relman, D.; Waddell, S.; Langford, P.; Sheehan, B.; Semple, L.; Wilkinson, K.; Wilkinson, R.; Ress, S.; M., H.; Levin, M. Acquired predisposition to mycobacterial disease due to autoantibodies to IFN-gamma. J. Clin. Invest. 2005, 115, 2480-2488. 
166. Höflich, C.; Sabat, R.; Rosseau, S.; Temmesfeld, B.; Slevogt, H.; Döcke, W.; Grütz, G.; Meisel, C.; Halle, E.; Göbel, U.; Volk, H.; Suttorp, N. Naturally occurring anti-IFN-gamma autoantibody and severe infections with Mycobacterium cheloneae and Burkholderia cocovenenans. Blood 2004, 103, 673-675.

167. Döffinger, R.; Helbert, M.; Barcenas-Morales, G.; Yang, K.; S., D.; Ceron-Gutierrez, L.; EspitiaPinzon, C.; Barnes, N.; Bothamley, G.; Casanova, J.; Longhurst, H.; DS., K. Autoantibodies to interferon-gamma in a patient with selective susceptibility to mycobacterial infection and organspecific autoimmunity. Clin. Infect. Dis. 2004, 38, 10-14.

168. Baerlecken, N.; Jacobs, R.; Stol, 1.M.; Schmidt, R.; Witte, T. Recurrent, multifocal Mycobacterium avium-intercellulare infection in a patient with interferon-gamma autoantibody. Clin. Infect. Dis. 2009, 49, 76-78.

169. Giovannoni, G.; Barbarash, O.; Casset-Semanaz, F.; King, J.; Metz, L.; Pardo, G.; Simsarian, J.; Sorensen, P.S.; Stubinski, B. Safety and immunogenicity of a new formulation of interferon beta1a (Rebif New Formulation) in a Phase IIIb study in patients with relapsing multiple sclerosis: 96-week results. Mult. Scler. 2009, 15, 219-228.

(C) 2010 by the authors; licensee MDPI, Basel, Switzerland. This article is an open-access article distributed under the terms and conditions of the Creative Commons Attribution license (http://creativecommons.org/licenses/by/3.0/). 